\title{
PENGARUH BLANDING BAHAN BAKAR PERTALITTE DAN ETANOL TERHADAP KINERJA MESIN SEPEDA MOTOR HONDA ABSOLUTE REVO 2008
}

\author{
Wahyu Oktavianto \\ Teknik Mesin, Fakultas Teknik \\ Universitas Maarif Hasyim Latif, Sidoarjo, Indonesia \\ e-mail : wahyu-oktavianto@student.umaha.ac.id
}

\begin{abstract}
ABSTRAK
Sepeda motor merupakan transportasi yang dijalankan oleh mesin berbahan bakar bensin. Bahan bakar bensin pada saat ini ada beberapa macam seperti premium, pertalite, pertamax, dan pertamax turbo yang masing-masing memiliki nilai oktan yang berbeda dan emisi gas buang yang dihasilkan juga berbeda. Oleh karena itu tidak dapat dihindari adanya percampuran antar jenis bahan bakar tersebut dengan blanding etanol. Metodologi penelitian ini dilakukan secara experimental pada motor Honda Absolute Revo 2008 dengan bahan bakar B100, B75, B50, dan B25 di Lab pengujian performa mesin gedung A8 Lt. 1 FT UNESA Jl. Ketintang Surabaya, untuk mengetahui pengaruh daya dan torsi menggunakan dynotest, sedangkan pengujian emisi gas buang menggunakan gas analyzer dan dilakukan di Lab bengkel otomotif SMK PGRI 3 SDA, Jl. Dr. Wahidin No.130B Sidoarjo. Desain pengujian yang digunakan adalah experiment. Data hasil pengujian dianalisa dengan cara mendeskripsikan dan merangkum hasil-hasil pengujian dalam bentuk grafik dan tabel dengan menggunakan Softwere Microsoft Excel. Berdasarkan hasil pengujian dan pembahasan penggunaan variasi campuran bahan bakar B100, B75, B50, dan B25 didapat kesimpulan bahwa variasi campuran bahan bakar B75 (25\% Ethanol;75\% Pertalite) menghasilkan ujuk kerja yang baik, pada sepeda motor Honda Absolute Revo Tahun 2008, torsi maksimum dicapai 7,01 Nm putaran $6919 \mathrm{rpm}$, dan daya maksimum dicapai pada 7,9 Hp putaran $8928 \mathrm{rpm}$. Konsumsi bahan bakar lebih hemat B100 pada putar 1500 sampai 9000 rpm dibandingkan B75, B50, dan B25, sedangkan emisi gas buang yang paling ramah lingkungan pada B75 dengan kadar CO 0,51\%vol dan HC 404,6 ppmvol.
\end{abstract}

Kata kunci: blending, daya, ethanol , pertalite, torsi.

\section{PENDAHULUAN}

Motor bakar yaitu jenin mesin internal combustion engine yang dapat menghasilkan energi mekanik. Energi itu diperoleh dari hasil proses pembakaran dalam salah satu contohnya sepeda motor. Sepeda motor merupakan merupakan alat transportasi yang digerakan oleh mesin berbahan bakar bensin.

Namun di era modern saat ini sepeda motor 2 langkah telah banyak ditinggalkan dikarenakan boros bahan bakar, dan masyarakat banyak yang beralih ke motor 4 langkah dikarenakan lebih hemat dibandingkan motor 2 langkah.

Bahan bakar yang dapat digunakan saat ini ada beberapa jenis antara lainnya seperti premium, pertalite, pertamax, pertamax turbo. Jenis masingmasing bahan bakar tersebut memiliki angka oktan yang berbeda.Pada tekanan tertentu bahan bakar menyala seiring adanya gaya tekanan pada piston yang menaikan temperature di dalam ruang silinder. Penyalaan ini dikarenakan adanya percikan api dari pengapian busi yang dapat menyebabkan destonasi. Destonasi adalah terjadinya nyala api yang tidak terduga selain nyala api pada busi (suyanto, 1989:258-259).

Pemilihan bahan bakar yang dapat mengacu terhadap perbandingan kopresi disetiap sepeda motor. Yang diperlukan mesin sepeda motor adalah jenis bahan bakar yang sesuai spesifikasi mesin itu sendiriagar dapat bekerja dengan baik dan menghasilkan cara kerja yang baik, untuk pemakaian mesin sepeda motor tidak lepas dari penggunaan jenis bahan bakar yang dipakai untuk memperoleh hasil kinerja mesin yang optimal diantaranya daya dan torsi.

Adapun tujuan penelitian ini adalah untuk menguji torsi, daya, konsumsi bahan bakar, dan emisi gas buang pada Honda Absolute Revo 2008

\section{METODE PENELITIAN}

\section{Tempat dan Waktu Analisa}

Tempat penganalisaan Pengambilan data untuk pembuatan skripsi ini dilakukan di Laboratorium Pengujian Performa Mesin Gedung A8 Lt. 1 FT UNESA Jl. Ketintang Surabaya untuk uji Dynotest, dan pengambilan data emisi gas buang dilakukan di 
SMK PGRI 3 SIDOARJO, serta uji konsumsi bahan bakar dilaksanakan di halaman UMAHA. Waktu Penelitian Penelitian ini dilaksanakan kurang lebih selama 8 bulan, dari bulan Februari 2019 sampai bulan September 2019.

\section{Obyek Penelitian}

Adapun obyek analisa yang digunakan adalah sepeda motor Honda Absolute 110cc Tahun 2008.

Spesifikasi sepeda motor Honda Absolute Revo 110 cc tahun 2008

\begin{tabular}{|l|l|}
\hline Tipe Mesin & 4 Tak, SOHC \\
\hline Volume Silinder & 109.17 cc \\
\hline Daya Maksimal & 8,91hp @ 7500 rpm \\
\hline Torsi Maksimal & 0,86 kgf.m @ 6000 rpm \\
\hline Transmisi & Manual, 4 Percepatan \\
\hline Kopling & $\begin{array}{l}\text { Mutiple Wet Clutch } \\
\text { With Diaphram } \\
\text { Spring, Otomatis }\end{array}$ \\
\hline $\begin{array}{l}\text { Sistem Bahan } \\
\text { Bakar }\end{array}$ & Karburator \\
\hline Sistem Starter & Kick \\
\hline
\end{tabular}

\section{Pengukuran Variabel Penelitian}

Performa mesin diukur dengan chasis dynamometer sedangkan konsumsi bahan bahar diukur dengan buret atau gelas ukur dan emisi gas buang diukur dengan Exhaust gas analyzer (Variabel Kontrol Variable kontrol merupakan usaha untuk menghilangkan pengaruh variable variabel lain selain variabel bebas yang mempengaruhi hasil variabel terikat. Adapun variabel kontrol yang digunakan adalah sepeda motor Honda Absolute Revo 110cc Tahun 2008, putaran mesin, dan emisi gas buang yang dihasilkan.

\section{Peralatan dan Bahan Penelitian}

Peralatan dan bahan yang digunakan dalam penelitian ini adalah sebagai berikut:

\section{Tool set}

Toolsetterdiri dari kunci pas ring $8-24 \mathrm{~cm}$, obeng + obeng -, dan kunci inggris

\section{Rpm counter}

Rpm counter adalah alat yang digunakan untuk mengukur putaran yang diasilkan mesin. Adapun spesifikasinya adalah sebagai berikut:

1. Merk: BrainBee

2. Type: MGT-300

3. No seri: 080317000579

4. Tahun pembuatan: 2008

5. Buatan: Italia

6. Rpm counter: 0 - $9990 \mathrm{rpm}$

7. Resolution: $10 \mathrm{rpm}$

8. Power supply: $11-45 \mathrm{Vdc}$

9. Periodic control: 12 bulan

3. Chasis dynamometer
Chasis dynamometer adalah alat yang digunakan untuk mengukur torsi yang dihasilkan oleh mesin. Spesifikasi alat tersebut adalah sebagai berikut:

1. Nama : Rextor pro-dyno

2. Tegangan : $220 \mathrm{~V}, 50 / 60 \mathrm{~Hz}$

3. Range operasi : $6.000 \mathrm{rpm}$ dengan 150 gigi

4. Kemampuan : $15 \mathrm{KHz}$

5. Tipe sensor : digital pick up

6. Tipe input: logical level

7. Produksi : PT.Rextor Technology

\section{Stopwatch}

Stopwatch digunakan sebagai alat bantu dalam menghitung konsumsi bahan bakar pada saat pengujian. Spesifikasi alat tersebut adalah sebagai berikut:

1. Merk : Seiko

2. Penunjukan data : digital

3. Ketelitian : 0,01 detik

\section{Metode pengujian}

Untuk mendapatkan data penelitian yang akurat, maka pengujian dilakukan berdasarkan standar pengujian performa mesin SAE J1349, yaitu metode yang dilakukan pada kondisi bukaan throtle kontinyu mulai dari idle sampai bukaan throtle maximum (akselerasi). Data sensor putaran roller dengan pembebanan inersia dan putaran mesin secara otomatis akan terbaca data acquisition dan dikalkulasikan oleh program komputer. Setelah itu hasil kalkulasi torsi, daya, kecepatan, waktu, dan jarak tempuh ditunjukkan lewat monitor.

\section{Pengujian Peforma Mesin}

1. Menyiapkan dan memeriksa bahan dan peralatan yang akan digunakan

2. Menyiapkan kendaraan yang digunakan dalam penelitian pada kondisi standar sesuai spesifikasi awal motor (tune up)

3. Melepas selang dari tangki bahan bakar yang menuju ke karburator dan sambungkan ke selang dari fuel meter

4. Mengisi buret / gelas ukur pada fuel meter dengan bahan bakar premium secukupnya

5. Menyiapkan chassis dynamometer dan memastikan kondisi sesuai prosedur

6. Memasang tali pengikat pada kendaraan bermotor

7. Pasang inductive pickup sensor ke kabel busi

8. Hidupkan komputer, Pilih program sport dyno 33 kemudian Pilih menu Options kemudian pilih configuration

9. Pilih Tab Class of Dyno dan pilih vehicles, pilih Torque At Roller pada Torque calculation

10.Pilih Tab program, kemudian pilih 500 rpm pada RPM steps dan Pilih HP, Nm pada Units Power kemudian pilih KMH pada Units Speed lalu tekan $\mathrm{OK}$ 
11.Isi jenis kendaraan yang akan diuji, isi kapasitas silinder (cc kendaraan), Isi variable uji dan pilih using RPM clamp

12.Pilih factor correction (ISO 1585, SAE J1349, DIN 70020, JIS D10001)

13. Mengukur batas kecepatan mesin pada data aquisisi

14. Memasukkan data ambient temperature dan humidity

15. Start mesin

16.Operasikan mesin pada kecepatan rendah sampai suhu mesin mencapai $60^{\circ} \mathrm{C}$ ( warm up)

17. Naikkan posisi gigi persneling secara bertahap sampai pada gigi 4 dan stabilkan putaran mesin pada $3000 \mathrm{rpm}$, kemudian tekan tombol switch computer data acquisition satu kali

18. Naikkan putaran mesin hingga mencapai 9.000 rpm (perubahan putaran mesin dapat dilihat pada tachometer yang terdapat pada layar monitor) atau posisi top speed, kemudian tekan tombol switch computer data acquisition untuk pengambilan data

19. Pengambilan data pada tingkat putaran 3000 sampai $9.000 \mathrm{rpm}$ dengan rentang $500 \mathrm{rpm}$

20. Data akan tersimpan pada PC

21.Pengujian dan pengambilan data dilakukan sebanyak 9 (sembilan) kali agar data yang diambil valid.

22. Melakukan percobaan diatas untuk kelompok standar dengan bahan bakar Premium dan kelompok dengan bahan bakar Pertalite

23. Putaran mesin diturunkan secara perlahan sampai putaran idle

24. Untuk sesaat mesin dibiarkan pada putaran idle 25. Mesin dimatikan

26. Blower dimatikan

\section{Pengujian Konsumsi Bahan Bakar}

1. Kosongkan bahan bakar pada karburator

2. Tancapkan selang bahan bakar fuel meter ke karburator

3. Isi gelas ukur pada fuel meter dengan bahan bakar secukupnya

4. Start mesin sepeda motor atur pada putaran stabil untuk tiap pengambilan data putaran mesin $(1500,2000,3000$, dan seterusnya)

5. Atur volume bahan bakar $10 \mathrm{ml}$ pada gelas ukur, dan catat waktu yang diperlukan untuk menghabiskan volume bahan bakar tersebut pada tiap kecepatan

6. Untuk mengkhiri percobaan ini, matikan mesin dan lanjutkan pengujian dengan bahan bakar yang lain (Pertalite).

\section{Pengujian Emisi Gas Buang}

1. Pengecekan pada pipa gas buang (tidak terdapat kebocoran)

2. Menyiapkan alat ukur uji emisi kendaraan sesuai standar ISO 3930/OIML R-99
3. Memberi isolasi pada sambungan dan lubang pada knalpot agar tidak ada pemasukan udara pada sistem pembuangan

4. Melakukan kalibrasi exhaust gas analyzer

5. Menghidupkan mesin dan menjaga posisi temperatur mesin $60^{\circ} \mathrm{C}$

6. Gigi transmisi pada posisi netral

7. Memasukkan probe alat uji ke pipa gas buang sedalam $30 \mathrm{~cm}$ lalu tunggu 20 detik untuk pengambilan data konsentrasi gas $\mathrm{CO}$ dan $\mathrm{CO} 2$ dalam satuan persen (\% vol), dan HC dalam satuan ppm yang terukur pada alat uji.

8. Mencetak atau print hasil uji.

9. Melakukan percobaan untuk kelompok pemakaian bahan bakar premium dan pertalite

10. Putaran mesin diturunkan secara perlahan sampai putaran idle, dan untuk sesaat mesin dibiarkan pada putaran idle

11. Mesin dan Blower dimatikan

\section{HASIL DAN PEMBAHASAN}

Tabel 1. Data daya dan torsi motor 3 kali pengujian dengan menggunakan bahan bakar B100

\begin{tabular}{|l|c|c|c|c|}
\hline & \multicolumn{3}{|c|}{ B100(0\%ETHANOL;100\%PERTALITE) } \\
\hline NO & $\begin{array}{l}\text { RPM- } \\
\text { DAYA }\end{array}$ & $\begin{array}{l}\text { DAYA } \\
(\mathrm{HP})\end{array}$ & $\begin{array}{l}\text { RPM- } \\
\text { TORSI }\end{array}$ & $\begin{array}{l}\text { TORSI } \\
(\mathrm{Nm})\end{array}$ \\
\hline UJI 01 & 8866 & 7,4 & 6651 & 6,92 \\
\hline UJI 02 & 8885 & 7,5 & 6691 & 6,95 \\
\hline UJI 03 & 8779 & 7,5 & 6500 & 6,93 \\
\hline
\end{tabular}

Tabel 2. Data daya dan torsi motor 3 kali pengujian dengan menggunakan bahan bakar B75

\begin{tabular}{|l|l|l|l|l|}
\hline \multicolumn{4}{|c|}{ B75(25\%ETHANOL;75\%PERTAL } \\
\hline ITE $)$
\end{tabular}

Tabel 3. Data daya dan torsi motor 3 kali pengujian dengan menggunakan bahan bakar B50

\begin{tabular}{|l|l|l|l|l|}
\hline & \multicolumn{4}{|l|}{ B50(50\%ETHANOL;50\%PERTALITE) } \\
\hline & $\begin{array}{l}\text { RPM- } \\
\text { DAYA }\end{array}$ & $\begin{array}{l}\text { DAYA } \\
\text { (HP) }\end{array}$ & $\begin{array}{l}\text { RPM- } \\
\text { TORSI }\end{array}$ & $\begin{array}{l}\text { TORSI } \\
(\text { Nm })\end{array}$ \\
\hline UJI 01 & 8480 & 7,8 & 6451 & 6,96 \\
\hline UJI 02 & 8493 & 7,8 & 7200 & 6,91 \\
\hline UJI 03 & 9036 & 7,8 & 7527 & 6,91 \\
\hline
\end{tabular}

Grafik torsi terhadap Rpm mesin Berdasarkan grafik hasil pengujian menunjukan bahwa adanya perbedaan torsi antara yang mengkonsumsi bahan bakar blanding pertalite dan Ethanol B100, B75, B50, dan B25, Dari grafik di atas torsi yang menggunakan bahan bakar blanding B75 (Ethanol 25\%;Pertalite 75\%) cenderung lebih tinggi dari pada torsi yang menggunakan bahan bakar 
B100, B50, dan B25, sedangkan variasi campuran yang terbaik adalah B75.

Tabel 4. Data daya dan torsi motor 3 kali pengujian dengan menggunakan bahan bakar B25

\begin{tabular}{|l|l|l|l|l|}
\hline & \multicolumn{4}{|l|}{ B25(75\%ETHANOL;25\%PERTALITE) } \\
\hline & $\begin{array}{l}\text { RPM- } \\
\text { DAYA }\end{array}$ & $\begin{array}{l}\text { DAYA } \\
\text { (HP) }\end{array}$ & $\begin{array}{l}\text { RPM- } \\
\text { TORSI }\end{array}$ & $\begin{array}{c}\text { TORSI } \\
\text { (Nm) }\end{array}$ \\
\hline UJI 01 & 9115 & 7,6 & 7651 & 6,72 \\
\hline UJI 02 & 9126 & 7,6 & 7734 & 6,48 \\
\hline UJI 03 & 9505 & 7,2 & 7523 & 5,98 \\
\hline
\end{tabular}

Torsi maksimum untuk B75 terjadi pada putaran $6918 \mathrm{rpm}$ yaitu 7,01 Nm, sedangkan torsi maksimum B50 terjadi pada putaran 7527 rpm yaitu 6,91 Nm dan untuk B75 terjadi pada putaran $7734 \mathrm{rpm}$ yaitu $6,48 \mathrm{Nm}$.

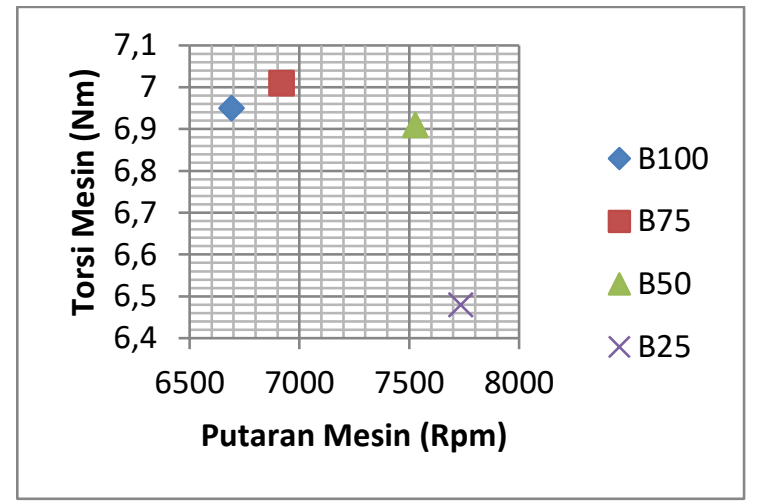

Gambar 1. Grafik Hasil Uji Torsi Maksimal

Tabel 5. uji torsi maksimal

\begin{tabular}{|l|l|l|l|l|l|}
\hline \multirow{2}{*}{ NO } & PUTARAN & \multicolumn{5}{|c|}{ TORSI (Nm) } \\
\cline { 3 - 6 } & $(\mathrm{Rpm})$ & B100 & B75 & B50 & B25 \\
\hline 1 & 6691 & 6,95 & & & \\
\hline 2 & 6918 & & 7,01 & & \\
\hline 3 & 7527 & & & 6,91 & \\
\hline 4 & 7734 & & & & 6,48 \\
\hline
\end{tabular}

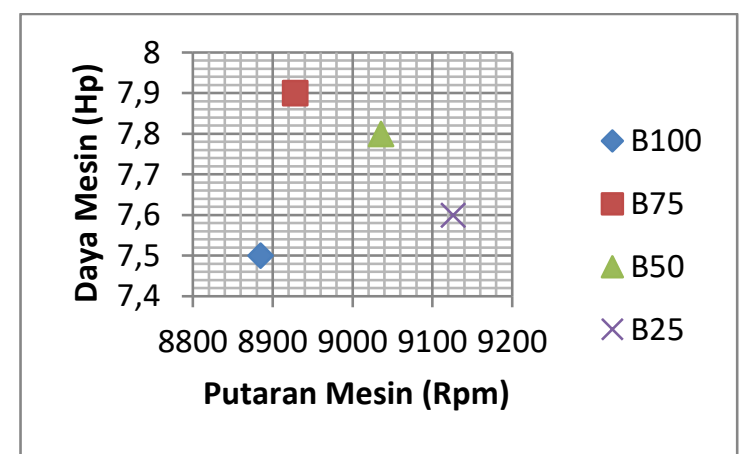

Gambar 2. grafik hasil uji daya maksimal

Grafik yang menghasilkan daya pada putaran mesin. Berdasarkan grafik hasil pengujian. menunjukan adanya perbedaan daya mesin antara yang menggunakan blanding bahan bakar pertalite dan Ethanol B100, B75, B50, dan B25, dari grafik di atas daya mesin yang menggunakan bahan bakar
B75 (Ethanol 25\%: Pertalite 75\%) cenderung lebih tinggi dari pada torsi yang menggunakan bahan bakar B100, B50, B25, namun variasi blanding bahan bakar tertinggi diperoleh dari pengujian B75 (Ethanol 25\%, Pertalite 75\%).

Tabel 6. Uji daya maksimal

\begin{tabular}{|l|l|l|l|l|l|}
\hline \multirow{2}{*}{ NO } & \multirow{2}{*}{$\begin{array}{l}\text { PUTARAN } \\
\text { (Rpm) }\end{array}$} & \multicolumn{5}{|c|}{ DAYA (Hp) } \\
\cline { 3 - 6 } & & B100 & B75 & B50 & B25 \\
\hline 1 & 8885 & 7,5 & & & \\
\hline 2 & 8928 & & 7,9 & & \\
\hline 3 & 9036 & & & 7,8 & \\
\hline 4 & 9126 & & & & 7,6 \\
\hline
\end{tabular}

Daya maksimum untuk B75 terjadi pada putaran $8928 \mathrm{rpm}$ yaitu 7,9 Hp, sedangkan daya maksimum B50 terjadi pada putaran $9036 \mathrm{rpm}$ yaitu 7,8 Hp dan untuk B25 terjadi pada putaran 9126 rpm yaitu 7,6 Hp.

\section{Konsumsi bahan bakar}

Untuk mendapatkan konsumsi bahan bakar dalam sepeda motor yang akan diuji dengan varisi campuran bahan bakar pertalite dan ethanol B100, B75, B50, dan B25 dapat diketahui dengan menetapkan volume bahan bakar (sebesar $10 \mathrm{ml}$ ) kemudian dihitung waktu untuk menghabiskan volume bahan bakar tersebut dengan berbagai variasi putaran motor. Berikut disajikan table hasil penelitian pemakaian bahan bakar.

Untuk mendapatkan nilai konsumsi bahan bakar dapat dipergunakan rumus sebagai berikut:

Keterangan :

$$
F c=\frac{b}{t} \cdot \gamma f \cdot \frac{3600}{1000} \cdot \frac{\mathrm{kg}}{\mathrm{jam}}
$$

FC = Konsumsi bahan bakar [kg/jam $]$

$b \quad=$ Volume bahan bakar selama t detik [ml]

$t=$ Waktu untuk menghabiskan bahan bakar sebanyak b ml [det]

$\gamma f=$ Berat spesifikasi bahan bakar [kg/lt]

Dari data hasil pengujian di dapatkan sbb:

$b \quad=10 \mathrm{ml}$

$\gamma f=0,715 \mathrm{~s} / \mathrm{d} \quad 0,780 \mathrm{~kg} / \mathrm{lt}$ untuk bahan petalite

$t \quad=225,19 \mathrm{det}$

maka:

$$
\begin{aligned}
& F_{C}=\frac{10}{225,19} \cdot 0750 \cdot \frac{3600}{1000} \cdot \frac{\mathrm{kg}}{\mathrm{jam}} \\
& F_{C}=0,12 \frac{\mathrm{kg}}{\mathrm{jam}}
\end{aligned}
$$

Perbandingan konsumsi bahan bakar ethanol dan pertalite Berdasarkan tabel 4.14 menunjukan bahwa ada perbedaan hasil perhitungan Fc ratarata antara campuran bahan bakar ethanol dan pertalite B100, B75, B50,dan B25. Sepeda motor 
absolute revo 110 yang menggunakan bahan bakar B100 membutuhkan rata-rata $F c$ 0,532 Kg/jam, bahan bakar B75 membutuhkan rata-rata $\mathrm{Fc} 0,540$ $\mathrm{Kg} /$ jam, bahan bakar B50 membutuhkan rata-rata Fc 0,650 Kg/jam, dan bahan bakar B25 membutuhkan rata-rata Fc 0,585 Kg/jam.

Berdasarkan data tersebut dapat disimpulkan penggunaan bahan baka B100 (100\%Pertalite) lebih irit jika dibandingkan konsumsi bahan bakar yang digunakan adalah bahan bakar campuran, namun jika bahan bakar tersebut dicampuran B75 (25 \%Ethanol: 75 \%Pertalite) lebih irit di bandingkan bahan bakar B50 dan B25.

Tabel 7. Konsumsi Bahan Bakar

\begin{tabular}{|c|c|c|c|c|c|}
\hline & \multirow[t]{2}{*}{ RPM } & \multicolumn{4}{|c|}{$\begin{array}{l}\text { Konsumsi Bahan Bakar } \\
\text { (Fc Kg/jam) }\end{array}$} \\
\hline & & B100 & B75 & B50 & B25 \\
\hline \multirow{16}{*}{$\begin{array}{l}\text { Dृ } \\
\text { ב }\end{array}$} & 1500 & 0,188 & 0,157 & 0,173 & 0,175 \\
\hline & 2000 & 0,207 & 0,199 & 0,254 & 0,195 \\
\hline & 2500 & 0,233 & 0,244 & 0,276 & 0,208 \\
\hline & 3000 & 0,274 & 0,275 & 0,301 & 0,233 \\
\hline & 3500 & 0,302 & 0,307 & 0,350 & 0,273 \\
\hline & 4000 & 0,335 & 0,445 & 0,410 & 0,296 \\
\hline & 4500 & 0,372 & 0,489 & 0,446 & 0,314 \\
\hline & 5000 & 0,405 & 0,544 & 0,501 & 0,361 \\
\hline & 5500 & 0,479 & 0,575 & 0,557 & 0,427 \\
\hline & 6000 & 0,539 & 0,601 & 0,707 & 0,491 \\
\hline & 6500 & 0,579 & 0,664 & 0,752 & 0,692 \\
\hline & 7000 & 0,741 & 0,694 & 0,991 & 0,903 \\
\hline & 7500 & 0,865 & 0,738 & 1,046 & 0,976 \\
\hline & 8000 & 0,945 & 0,818 & 1,170 & 1,132 \\
\hline & 8500 & 1,000 & 0,912 & 1,215 & 1,282 \\
\hline & 9000 & 1,062 & 0,975 & 1,250 & 1,413 \\
\hline \multicolumn{2}{|c|}{$\begin{array}{l}\text { rata-rata } \\
\text { Fc }\end{array}$} & 0.532 & 0.540 & 0.650 & 0.585 \\
\hline
\end{tabular}

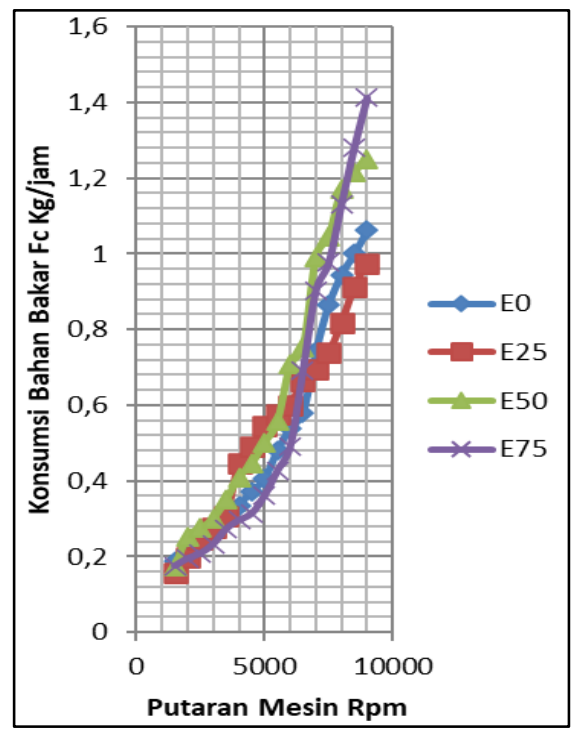

Gambar 3. Grafik Konsumsi Bahan Bakar

\section{Emisi gas buang}

Tabel 8. Data uji gas buang bahan bakar B100 (0\% Ethanol; $100 \%$ Pertalite)

\begin{tabular}{|l|l|l|l|l|l|l|}
\hline NO & $\begin{array}{l}\text { Kandu- } \\
\text { ngan } \\
\text { Gas } \\
\text { Buang }\end{array}$ & Satuan & Uji 1 & Uji 2 & $\begin{array}{l}\text { Uji } \\
3\end{array}$ & $\begin{array}{l}\text { Rata- } \\
\text { rata }\end{array}$ \\
\hline 1 & C0 & (\%Vol) & 0,25 & 0,4 & 0,35 & 0,33 \\
\hline 2 & CO2 & (\%Vol) & 3,4 & 3,7 & 3,5 & 3,5 \\
\hline 3 & HC & (ppmvol) & 503 & 515 & 510 & 509,3 \\
\hline 4 & 02 & $(\%$ Vol) & 15,68 & 15,88 & 15,7 & 15,75 \\
\hline 5 & Nox & (ppmvol) & 0 & 0 & 0 & 0 \\
\hline 6 & Lambda & & 2 & 2 & 2 & 2 \\
\hline
\end{tabular}

Tabel 9. Data uji gas buang bahan bakar B75 (25\% Ethanol; 75\% Pertalite)

\begin{tabular}{|c|c|c|c|c|c|c|}
\hline N0 & $\begin{array}{c}\text { Kandungan } \\
\text { Gas Buang }\end{array}$ & Satuan & Uji 1 & Uji 2 & Uji 3 & $\begin{array}{c}\text { Rata- } \\
\text { rata }\end{array}$ \\
\hline 1 & C0 & (\%Vol) & 0,54 & 0,65 & 0,35 & 0,51 \\
\hline 2 & C02 & (\%Vol) & 3,6 & 4,2 & 3,8 & 3,8 \\
\hline 3 & HC & (prmulol) & 401 & 408 & 405 & 404,6 \\
\hline 4 & 02 & (\%Vol) & 14,64 & 14,93 & 14,72 & 14,76 \\
\hline 5 & Nex & (2pmurol) & 0 & 0 & 0 & 0 \\
\hline 6 & Lambda & & 2 & 2 & 2 & 2 \\
\hline
\end{tabular}

Tabel 10. Data uji gas buang bahan bakar B50 (50\% Ethanol; 50\% Pertalite)

\begin{tabular}{|c|c|c|c|c|c|c|}
\hline N0 & $\begin{array}{c}\text { Kandungan } \\
\text { Gas Buang }\end{array}$ & Satuan & Uji 1 & $\begin{array}{c}\text { Uji } \\
2\end{array}$ & Uji 3 & $\begin{array}{c}\text { Rata- } \\
\text { rata }\end{array}$ \\
\hline 1 & C0 & (\%Vol) & 0,07 & 0,1 & 0,08 & 0,08 \\
\hline 2 & C02 & (\%Vol) & 2,1 & 2,5 & 2,2 & 2,2 \\
\hline 3 & HC & (prmul) & 651 & 670 & 660 & 660,3 \\
\hline 4 & 02 & (\%Vol) & 17,65 & 18,1 & 17,85 & 17,86 \\
\hline 5 & Nex & (prmul) & 0 & 0 & 0 & 0 \\
\hline 6 & Lambda & & 2 & 2 & 2 & 2 \\
\hline
\end{tabular}

Tabel 11. Data uji gas buang bahan bakar B75 (75\% Ethanol; 25\% Pertalite)

\begin{tabular}{|c|c|c|c|c|c|c|}
\hline NO & $\begin{array}{c}\text { Kandungan } \\
\text { Gas Buang }\end{array}$ & Satuan & Uji 1 & Uji 2 & Uji 3 & $\begin{array}{c}\text { Rata- } \\
\text { rata }\end{array}$ \\
\hline 1 & C0 & (\%Vol) & 0,16 & 0,3 & 0,22 & 0,22 \\
\hline 2 & C02 & (\%Vol) & 2 & 2,5 & 2,2 & 2,23 \\
\hline 3 & HC & (pamulol) & 1809 & 1820 & 1810 & 1813 \\
\hline 4 & 02 & (\%Vol) & 17,12 & 17,2 & 17,15 & 17,16 \\
\hline 5 & Nex & (prmulol) & 0 & 0 & 0 & 0 \\
\hline 6 & Lambda & & 2 & 2 & 2 & 2 \\
\hline
\end{tabular}


Pada penguijian perbedaan emisi gas buang menggunakan ethanol dan pertalite, elemen gas buang yang diteliti adalah presentase volume gas $\mathrm{CO}, \mathrm{CO}_{2}, \mathrm{O}_{2}$ dan $\mathrm{HC}$.

Tabel 12. Hasil Uji Emsi Gas Buang

\begin{tabular}{|c|c|c|c|c|c|c|}
\hline No & $\begin{array}{l}\text { Kandungan } \\
\text { Gas Buang }\end{array}$ & Satuan & B100 & B75 & B50 & B25 \\
\hline 1 & $\mathrm{CO}$ & (\% Vol) & 0,33 & 0,51 & 0,08 & 0,22 \\
\hline 2 & $\mathrm{CO}_{2}$ & (\% Vol) & 3,5 & 3,8 & 2,2 & 2,23 \\
\hline 3 & $\mathrm{HC}$ & (ppaxyol) & 509,3 & 404,6 & 660,3 & 1813 \\
\hline 4 & $\mathrm{O}_{2}$ & $(\% \mathrm{Vol})$ & 15,75 & 14,76 & 17,86 & 17,16 \\
\hline 5 & Nex & (papaxel) & 0 & 0 & 0 & 0 \\
\hline 6 & Lambda & & 2 & 2 & 2 & 2 \\
\hline
\end{tabular}

Hasil olah data pada tabel menunjukkan bahwa ada perbedaan hasil analisa gas buang ratarata hasil blanding bahan bakar pertalite dan ethanol B100, B75, B50, dan B25. Sepeda motor absolute revo $110 \mathrm{cc}$ yang menggunakan bahan bakar B100 menghasilkan rata-rata kadar HC 509, 3 ppmvol dan kadar CO2 3,5 \%Vol.

bahan bakar B75 menghasilkan rata-rata kadar HC 404,6 ppmvol dan kadar CO2 3,8 \%Vol. bahan bakar B50 menghasilkan rata-rata kadar HC 660,3 ppmvol dan kadar CO2 2,2 \%Vol. bahan bakar B25 menghasilkan rata-rata kadar HC 1813 ppmvol dan kadar CO2 2,23\%Vol. Berdasarkan data tersebut dapat disimpulkan penggunaan bahan bakar B75 (25 \% Ethanol dan $75 \%$ Pertalite) terjadi proses pembakaran paling sempurna dibandingkan bahan bakar B100, B50 dan B25, namun B25 (75 \% Ethanol) terjadi proses pembakaran kurang sempurna jika dibandingkan konsumsi bahan bakar yang menggunakan blanding bahan bakar B100, B75, dan B50.

\section{PENUTUP}

\section{Kesimpulan}

1. Torsi maksimum menggunakan bahan bakar campuran B100 (0\%ethanol) terjadi pada putaran $6691 \mathrm{rpm}$ yaitu 6,95 Nm. sedangkan variasi campuran terbaik menggunakan bahan bakar B25. Torsi maksimum pada B25 terjadi pada putaran $6918 \mathrm{rpm}$ yaitu 7,01 Nm, sedangkan torsi maksimum untuk B50 terjadi pada putaran7527 rpm yaitu 6,91 $\mathrm{Nm}$, dan sedangkan torsi maksimum untuk B75 terjadi pada putaran $7734 \mathrm{rpm}$ yaitu $6,48 \mathrm{Nm}$.

2. Daya maksimum menggunakan bahan bakar B100 (0\%ethanol) terjadi pada putaran 8885 rpm yaitu 7,5 Hp. Sedangkan variasi campuran bahan bakar terbaik adalah B75. Daya maksimum untuk B75 terjadi pada putaran 8928 rpm yaitu 7,9 Hp sedangkan daya maksimum untuk B50 terjadi pada putaran $9036 \mathrm{rpm}$ yaitu 7,8 Hp, sedangkan daya maksimum untuk B25 terjadi pada putaran $9126 \mathrm{rpm}$ yaitu 7,6 Hp.

3. Konsumsi bahan bakar (Fc rata-rata) menggunakan bahan bakar B100 (0 \% ethanol) lebih irit jika dibandingkan konsumsi bahan bakar yang menggunakan bahan bakar B75, B50, dan B25. Namun jika bahan bakar tersebut dicampur bahan bakar B75 (25 \% ethanol; $75 \%$ pertalite) lebih irit jika dibandingkan bahan bakar B50 dan B25. Data hasil pengujian adalah sebagai berikut : bahan bakar B100 membutuhkan rata-rata Fc 0,532 Kg/jam, bahan bakar B75 membutuhkan rata-rata Fc 0,540 $\mathrm{Kg} / \mathrm{jam}$, bahan bakar B50 membutuhkan ratarata $\mathrm{Fc} 0,650 \mathrm{Kg} / \mathrm{jam}$, bahan bakar $\mathrm{B} 25$ membutuhkan rata-rata Fc 0,585 Kg/jam.

4. Analisa gas buang rata-rata menggunakan bahan bakar B100 $(0 \%$ ethanol $)$ terjadi proses pembakaran yang sempurna, namun pada bahan bakar campuran B75 (25\% ethanol; $75 \%$ pertalite) terjadi proses pembakarn labih sempurna jika dibandingkan konsumsi bahan bakar yang menggunakan bahan bakar B50 dan B25. Data hasil pengujian adalah sebagai berikut : bahan bakar B100 menghasilkan rata-rata HC 509,3 ppmvol dan kadar $\mathrm{CO}_{2}$ 3,5 \% vol, bahan bakar B75 menghasilkan rata-rata HC 404,6 ppmvol dan kadar $\mathrm{CO}_{2}$ 3,8 \% vol, bahan bakar B50 menghasilkan rata-rata HC 660,3 ppmvol dan kadar $\mathrm{CO}_{2}$ 2,2 \% vol, dan bahan bakar B25 menghasilkan rata-rata HC 1813 ppmvol dan kadar $\mathrm{CO}_{2} 2,23 \%$ vol.

5. Variasi campuran bahan bakar B75 (25\% Ethanol: 75\% Pertalite) menghasilkan ujuk kerja paling baik, yaitu menghasilkan ujuk kerja mesin torsi yang tinggi pada 7,01 Nm dan Daya 7,9 Hp pada saat putaran tinggi.

\section{Saran}

1. Untuk penelitian lebih lanjut bisa dilakukan dengan cara yang sama namun dengan perbandingan bahan bakar yang lebih bervariasi.

2. Sebelum penelitian kondisi sepeda motor harus standart (setelah di tune up)

\section{DAFTAR PUSTAKA}

Afan Agrariksa, Fintas, Bambang Susilo, and Wahyunanto Agung Nugroho. 2013. "Uji Performansi Motor Bakar Bensin (On Chassis) Menggunakan Campuran Premium Dan Etanol Performance Test of Gasoline Engine (On Chassis) by Use Mixed Premium and Ethanol." Jurnal Keteknikan Pertanian Tropis dan Biosistem. 
Afifah, Y. N. (2016). ALIRAN TAK TUNAK FLUIDA NANO MAGNETOHIDRODINAMIK ( MHD) YANG MELEWATI BOLA.

Afifah, Y. N. (2019). (2019). Analysis of Unsteady Magneto Hydro Dynamic ( MHD ) Nano Fluid Flow Past A Sliced Sphere Analysis of Unsteady Magneto Hydro Dynamic ( MHD ) Nano Fluid Flow Past A Sliced Sphere. IOP Conference Series: Materials Science and Engineering, $\quad 494, \quad 012033$. https://doi.org/10.1088/1757899X/494/1/012033

Afifah, Y. N., \& Putra, B. C. (2018). Model Matematika Aliran Tak Tunak Pada Nano Fluid Melewati Bola Teriris Dengan Pengaruh Medan Magnet. Teknika: Engineering and Sains Journal, 2(2), 119-124.

Ariawan, I. W. B., Kusuma, I. G. B., \& Adnyana, I. W. B. (2016). Pengaruh Penggunaan Bahan Bakar Pertalite Terhadap Unjuk Kerja Daya, Torsi, Dan Konsumsi Bahan Bakar Pada Sepeda Motor Bertransmisi Otomatis. Jurnal METTEK.

Gunawan, E., Choifin, M., Khoirul Rosidin, M., Nur Afifah, Y., Lestariningsih, W., Sungging Pradana, M., ... Makki, A. (2019). Analysis of the Effect of Current Flow Variations in GTAW on SS 400 Plate Material Connected with SUS 304 Stainless Steel Plate Against Tensile Strength and Hardness with ER308L Electrodes. Journal of Physics: Conference Series, 1175(1). https://doi.org/10.1088/17426596/1175/1/012277

Jatmiko, Riva Suro, Kuntang Winangun, and Muhamad Malyadi. 2019. "PENGARUH PENCAMPURAN BAHAN BAKAR PERTALITE DENGAN BIO ETANOL TERHADAP PEFORMA MESIN INJEKSI YAMAHA VIXION 150CC TAHUN 2011." KOMPUTEK.

Luthfi, Muhammad, Dwi Ahmad, Muji Setiyo, and Suroto Munahar. 2018. "Uji Komposisi Bahan Bakar Dan Emisi Pembakaran Pertalite Dan Premium." Jakarta: Jurnal Teknologi Universitas Muhammadiyah Jakarta.

Nugraheni, Ika Kusuma, and Robby Haryadi. 2017. "PENGUJIAN EMISI GAS BUANG MOTOR BENSIN EMPAT TAK SATU SILINDER MENGGUNAKAN CAMPURAN BAHAN BAKAR PREMIUM DENGAN ETANOL." Jurnal Elemen.

Rifal, Mohamad, and Wawan Rauf. 2018. "Analisis Penggunaan Bahan Bakar Etanol-Pertalite Pada Motor Honda Scoopy 110 Cc." Gorontalo Journal of Infrastructure and Science Engineering.

Wiratno, Tego, Samsudi Rahardjo, and Joko Suwignyo. 2012. Pmk-113/Pmk.05/2013
PERHITUNGAN DAYA DAN KONSUMSI BAHAN BAKAR MOTOR BENSIN YAMAHA LS 100 CC.

Yunita Nur Afifah, MNH Qomarudin, \& Imamatul Ummah. (2020). Optimal Control Model Pemanenan Prey-Predator di Area Konservasi Ikan. Buana Matematika : Jurnal Ilmiah Matematika Dan Pendidikan Matematika, 10(1), 1-16. https://doi.org/10.36456/buanamatematik a.v10i1.2410 